\title{
PENGGUNAAN TEPUNG LIMBAH LABU KUNING DALAM RANSUM TERHADAP PENAMPILAN PRODUKSI AYAM RAS PETELUR
}

\author{
Devis. F. Komalig, Jein Rinny Leke*, J. Laihad, C. Sarajar \\ Fakultas Peternakan Universitas Sam Ratulangi Manado, 95115
}

\begin{abstract}
ABSTRAK
Tujuan penelitian ini adalah untuk mengetahui sampai sejauh mana penggunaan tepung limbah labu kuning memberikan pengaruh terhadap penampilan produksi ayam ras petelur. Sebanyak 100 ekor ayam petelur MB 402 berumur 42 minggu secara acak dialokasikan untuk 5 perlakuan dengan 5 ulangan terdiri dari 4 ekor ayam. Perlakuan yang digunakan adalah: Ransum Basal (R0), ransum basal 98\% + 2\% limbah labu kuning (lbk) (R1), ransum basal $96 \%+4 \%$ lbk (R2), ransum basal $94 \%+6 \%$ lbk (R3), ransum basal $92 \%+8 \%$ lbk (R4). Variabel yang diamati meliputi konsumsi ransum, hen day production (HDP) dan konversi pakan. Data dianalisis dengan rancangan acak lengkap (RAL). Penambahan limbah labu kuning dalam pakan tidak berpengaruh nyata $(\mathrm{P}>0.05)$ terhadap konsumsi ransum, HDP dan konversi. Berdasarkan hasil penelitian yang dilakukan dapat disimpulkan bahwa penggunaan limbah labu kuning dalam ransum sebanyak $8 \%$ memberikan hasil yang sama terhadap konsumsi ransum, HDP, Konversi.
\end{abstract}

Kata kunci : Ayam petelur, tepung limbah labu kuning, penampilan produksi

\begin{abstract}
THE EFFECT OF PUMPKIN WASTE MEAL IN LAYING HEN FEED ON PERFORMANS PRODUCTION. This research was to find out the use of pumpkin
\end{abstract}

\footnotetext{
*Korespondensi (corresponding author)

Email : rinileke@yahoo.com
}

waste meal on performance in the production of laying hens. The purpose of this research was to observe the effect of the use of pumpkin waste meal performance in the production of feed for laying hens. A total of $100 \mathrm{MB} 402$ laying hens from 42 week of age were randomly alloted to four dietary treatments with 5 replication groups of 4 hens. Dietary treatment were; basal diet (R0), basal diet 98\% + 2\% WCP (R1), basal diet $96 \%+4 \%$ WCP (R2), basal diet $94 \%+6 \%$ WCP (R3), basal diet 92\% + 8\% WCP (R4). The variable were the feed Consumption, hen day production, feed conversion. Data was analyzed with completely randomized Design ( CRD ). The addition of in the feed was not influenced significantly $(\mathrm{P}>0,05)$ to the feed consumption, hen day production, feed conversion. Based on the research that is done it can be concluted that the use of waste carrot pumpkins in the feed at the level of $8 \%$ show no significantly different result on the feed consumption, hen day production, feed conversion.

Keyword : Pumpkin waste meal, performance laying hens, performance of production

\section{PENDAHULUAN}

Salah satu usaha peternakan yang dapat menanggulangi kekurangan protein hewani dengan cepat adalah usaha peternakan ayam petelur. Keberhasilan usaha peternakan ayam petelur dipengaruhi 
oleh tiga faktor penting, yaitu bibit, pakan dan manajemen. Ayam ras sudah sejak lama dikenal dalam masyarakat dan diusahakan sebagai usaha sampingan maupun usaha peternakan (Susilorini et al, 2009). Ayam ras mempunyai potensi besar dalam usaha peternakan karena memiliki sifat-sifat dan kemampuan yang menguntungkan yaitu : telur mempunyai nilai gizi dan rasa yang lezat, ayam ras dapat memproduksi telur sekitar 250 - 300 butir pertahun.

Kendala utama dalam peternakan ayam ras adalah tingginya biaya untuk ransum. Biaya untuk ransum dapat mencapai $75 \%$ dari total biaya produksi. Harga ransum di Indonesia termasuk mahal karena sebagian besar bahan masih impor, seperti misalnya jagung, bungkil kedelai, dan tepung ikan. Oleh karena itu ransum perlu mendapatkan perhatian secara khusus, terutama kualitasnya. Ransum harus sesuai dengan kebutuhan ternak berdasarkan periode pemeliharaan atau tujuan produksi, untuk meningkatkan keuntungan ekonomis.

Pakan dalam usaha peternakan unggas memiliki peran pokok yang perlu mendapat perhatian selain bibit dan manajemen. Pakan merupakan komponen terbesar dari biaya produksi yaitu mencapai 60 - 70\%. Upaya yang bisa dilakukan untuk mengatasi masalah ketersediaan bahan pakan tersebut salah satunya adalah dengan memanfaatkan ketersediaan bahan pakan lokal yang bisa dijadikan sebagai bahan pakan ternak unggas. Bahan pakan lokal pada umumnya tersedia dalam jumlah yang sangat besar, sehingga memungkinkan harga untuk mendapatkan relatif lebih murah. Selain itu, ketersediaan yang dalam jumlah besar menjadikan keberadaan pakan tetap terjaga. Pemanfaatan limbah sebagai bahan pakan ternak merupakan alternatif dalam meningkatkan ketersediaan bahan baku penyusun ransum. Limbah mempunyai proporsi pemanfaatan yang besar dalam ransum. Limbah yang dimanfaatkan dalam bahan baku pakan berasal dari bagianbagian tanaman atau hewan yang di jadikan sebagai protein kasar, sumber energi, sumber protein dan sumber mineral. Bahan pakan kasar sebagian besar berasal dari limbah pertanian dan perkebunan. Sumber energi dan protein berasal dari sisa pengolahan bahan pangan dan bijibijian,buah-buahan dan sayuran, limbah usaha peternakan dan perikanan. Limbah labu kuning adalah salah satu dari sisa pengolahan bahan pangan.

Labu kuning memiliki potensi besar untuk dibudidayakan di Indonesia dan produksinya meningkat dari tahun ke tahun. Data produksi labu kuning tahun 2010 
menunjukkan produksi labu kuning di Indonesia 369.846 ton. Labu kuning (Cucurbita moschata) memiliki potensi sebagai sumber provitamin A nabati berupa $\beta$-karoten. Kandungan provitamin A dalam labu kuning sebesar $767 \mu \mathrm{g} / \mathrm{g}$ bahan. Selain itu, labu kuning juga mengandung vitamin C, serat dan karbohidrat yang cukup tinggi (Gardjito et al., 2005).

Labu kuning merupakan tanaman musiman, sehingga produksi labu kuning akan sangat besar ketika musimnya tiba. Tingginya produksi labu kuning di Indonesia tidak berimbang dengan pemanfaatan dari labu kuning tersebut. Selama ini labu kuning hanya dimanfaatkan untuk dibuat kolak, dodol atau hanya dikonsumsi sebagai sayuran. Oleh karena itu, perlu adanya olahan dari labu kuning yang lebih bervariasi namun tetap mempertahankan nilai gizi yang terdapat di dalam labu kuning tersebut.

Widayati dan Damayanti, (2000). juga mengatakan labu kuning adalah makanan yang mengandung kalori, karbohidrat, protein, lemak, mineral, (kalsium, fosfor, besi, natrium, kalium, tembaga,dan seng), beta karoten, tiamin, niasin, serat dan vitamin C. Paling banyak kandungan nutrisi labu adalah beta karoten yang merupakan pro vitamin A, yaitu yang akan di ubah menjadi vitamin A. Labu juga merupakan sumber serat dan asam lemak tak jenuh tunggal, yang baik untuk kesehatan pencernaan dan jantung.

Labu kuning juga kaya akan kandungan $\beta$-Karoten. Keunggulan $\beta$ Karoten, antara lain adalah dapat meningkatkan sistem imunitas serta mencegah penyakit jantung dan kanker. Dikatakan sebagai kaya $\beta$-Karoten sebab kandungan karotennya sangat tinggi, seperti lutein, zeaxanthin, yang memberi warna kuning pada labu kuning yang membantu melindungi tubuh dengan menetralkan molekul oksigen jahat yang disebut juga radikal bebas. Penggunaan produk kaya karotenoid seperti monakolin dan $\beta$-Karoten dalam ransum unggas dapat menghasilkan telur rendah kolesterol.

Sehubungan dengan itu maka dilakukan penelitian: Penggunaan tepung limbah labu kuning dalam ransum terhadap penampilan produksi ayam ras petelur. Tujuan penelitian ini adalah untuk mengetahui sampai sejauh mana penggunaan tepung limbah labu kuning memberikan pengaruh terhadap penampilan produksi ayam ras petelur. 


\section{MATERI DAN METODE PENELITIAN}

\section{Materi Penelitian}

Materi yang digunakan dalam penelitian ini adalah ayam ras petelur fase layer MB 402 berumur 42 minggu, digunakan sebanyak 100 ekor. Pakan yang diberikan terdiri dari jagung kuning, dedak halus, tepung ikan, $\mathrm{CaCO}_{3}$, konsentrat dan tepung labu kuning sebagai perlakuan. Kandungan zat makanan bahan pakan dapat dilihat pada Tabel 1, komposisi zat-zat makanan pakan perlakuan pada penelitian ini dapat dilihat pada Tabel 2. Pengamatan dilakukan selama 8 minggu. Kandang yang digunakan adalah kandang battery yang terbuat dari kawat dengan ukuran panjang $37 \mathrm{~cm}$, tinggi bagian depan $40 \mathrm{~cm}$, dan tinggi bagian belakang $30 \mathrm{~cm}$. Secara keseluruhan kandang battery dilengkapi tempat pakan dan tempat minum yang terbuat dari pipa dibelah menjadi dua bagian.

Tabel.1. Kandungan Zat Makanan (\% Bahan kering) Bahan Pakan penelitian

\begin{tabular}{lcccccc}
\hline \multicolumn{1}{c}{ Bahan makanan } & Protein & Lemak & $\begin{array}{l}\text { Serat } \\
\text { kasar }\end{array}$ & Ca & P & ME(Kkal) \\
\hline Jagung Kuning $^{* * *}$ & 8,8 & 3,9 & 2 & 0,02 & 0,28 & 3350 \\
Dedak Halus $^{* *}$ & 12 & 13 & 12 & 0,12 & 0,5 & 1630 \\
Tepung Ikan $^{* *}$ & 60 & 9 & 1 & 5,5 & 0,3 & 2830 \\
CaCO3 $^{* * *}$ & - & - & - & 29,4 & - & - \\
Konsentrat Cal 9.36 $^{* * *}$ & 29 & 10 & 7 & 3 & 2 & 2600 \\
T. Limb. Labu Kuning $^{*}$ & 23,14 & 14,59 & 17,48 & 0,76 & 0,75 & 3882,4 \\
\hline
\end{tabular}

Keterangan: * Hasil Analisa Laboratorium Ilmu dan Teknologi Pakan Fakultas Peternakan IPB .2015.

** Hasil perhitungan tabel komposisi nutrisi bahan pakan NRC (1994)

*** Sumber PT. Japfa 
Tabel.2. Kandungan Zat Makanan Pakan Perlakuan .

\begin{tabular}{lccccc}
\hline \multirow{2}{*}{ Komposisi Zat-zat Makanan } & \multicolumn{5}{c}{ Persentase (\%) } \\
\cline { 2 - 6 } & $\mathrm{R}_{0}$ & $\mathrm{R}_{1}$ & $\mathrm{R}_{2}$ & $\mathrm{R}_{3}$ & $\mathrm{R}_{4}$ \\
\hline Protein & 17,58 & 17,69 & 17,80 & 17,91 & 18,02 \\
Lemak & 4,33 & 4,54 & 4,74 & 4,95 & 5,15 \\
Serat kasar & 6,74 & 6,95 & 7,17 & 7,38 & 7,60 \\
$\mathrm{Ca}$ & 2,66 & 2,62 & 2,58 & 2,55 & 2,51 \\
$\mathrm{P}$ & 0,74 & 0,74 & 0,74 & 0,74 & 0,74 \\
ME (Kkal) & 2745,00 & 2767,75 & 2790.50 & 2813.24 & 2835,99 \\
\hline
\end{tabular}

Keterangan : Berdasarkan perhitungan Tabel 1.

Energi Metabolis 70\% x Energi Bruto (Schaible, 1970)

\section{Metode penelitian}

Rancangan percobaan yang digunakan dalam penelitian ini adalah rancangan acak lengkap (RAL) (Steel dan Torrie, 1994). Perlakuan yang dilakukan sebanyak dengan 5 perlakuan dan 5 ulangan sehingga terdapat 25 unit perlakuan, dimana pada masing-masing unit terdiri dari 4 ekor ayam, sehingga jumlah ayam yang digunakan adalah 100 ekor. Perlakuan disusun berdasarkan iso energi dan iso protein sesuai dengan perlakuan sebagai berikut :

$\mathrm{R} 0=$ Ransum Basal

$\mathrm{R} 1$ = Ransum Basal 98\% + 2\% limbah labu kuning

$\mathrm{R} 2=$ Ransum Basal 96\% + 4\% limbah labu kuning

R3 = Ransum Basal 94\% + 6\% limbah labu kuning
$\mathrm{R} 4=$ Ransum Basal 92\% + 8\% limbah labu kuning

Prosedur pembuatan tepung limbah labu kuning dapat dilihat pada gambar 1.

Variabel yang diamati dalam penelitian meliputi:

1. Konsumsi ransum(gram/ekor)

Dihitung dengan cara menimbang sejumlah pakan yang diberikan (gram) dikurangi sejumlah pakan yang tersisa (gram) yang dilakukan setiap 24 jam sekali. (Anggorodi, 1985). Konsumsi pakan setiap minggu kemudian dijumlahkan untuk mengetahui konsumsi pakan total selama penelitian.

2. Produksi telur (HDP).

Produksi telur harian dihitung dari sejumlah telur yang dikoleksi dibagi dengan sejumlah ayam petelur dalam 
Jurnal Zootek (“Zootek” Journal) Vol. 36 No. 2 : 342 - 352 (Juli 2016) ISSN 0852 -2626

kurun waktu tertentu pada setiap Konversi ransum

perlakuan (Fujiwara et al., 2008).

3. Konversi ransum.

Dihitung menurut Olgun et al.

$$
=\frac{\text { Konsumsi ransum }\left(\frac{\mathrm{g}}{\text { ekor }} / \text { hari }\right)}{\operatorname{Egg~mass~}\left(\frac{\mathrm{g}}{\text { ekor }} / \text { hari }\right)}
$$

(2009) sebagai berikut:

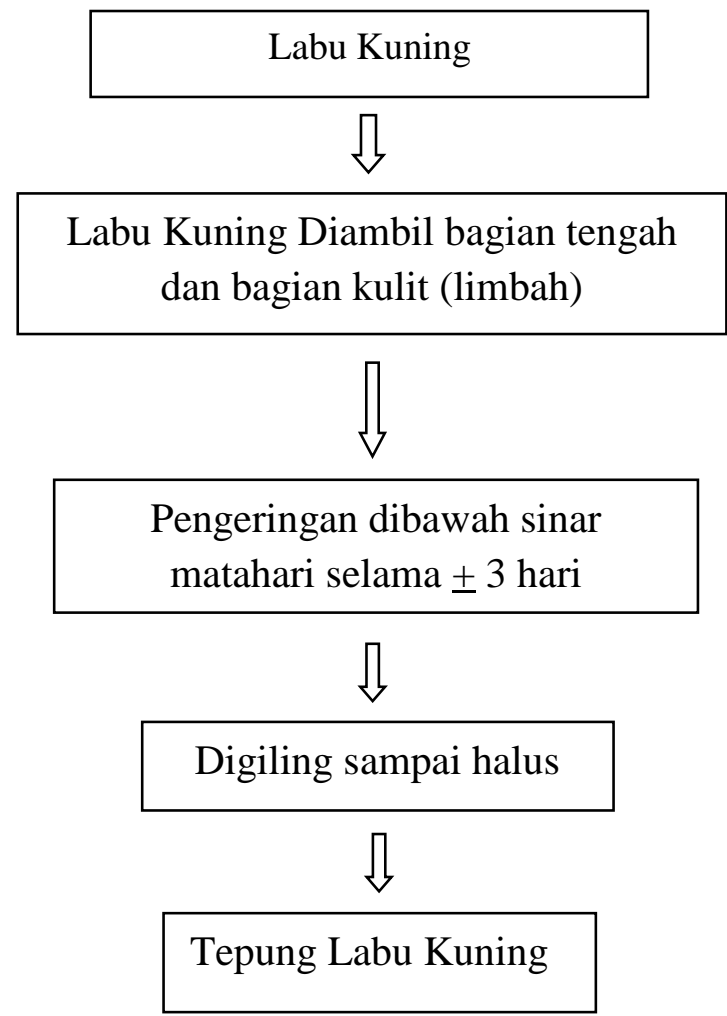

Gambar 1. Pembuatan tepung labu kuning. 


\section{HASIL DAN PEMBAHASAN}

\section{Pengaruh perlakuan Terhadap Konsumsi Ransum (gram/ekor)}

Ayam mengkonsumsi pakan untuk memenuhi kebutuhan energy, dimana energi tersebut digunakan untuk fungsi- fungsi tubuh dan untuk melancarkan reaksi - reaksi sintesis dari tubuh. Konsumsi pakan dinyatakan dengan satuan tertentu $(\mathrm{g} / \mathrm{kg})$ dan dalam waktu tertentu misalnya harian, mingguan atau waktu periode tertentu. Konsumsi pakan merupakan hal terpenting, karena berhubungan dengan pemenuhan kebutuhan baik untuk hidup pokok maupun untuk produksi (Yantimala, 2011). Meningkatnya ransum yang dikonsumsi akan memberikan kesempatan pada tubuh untuk meretensi zat zat makanan yang lebih banyak, kebutuhan protein zat - zat makanan yang lebih banyak, sehingga kebutuhan protein terpenuhi (Abun, 2005).

Hasil konsumsi ransum selama penelitian dari masing-masing perlakuan diperoleh rataan konsumsi pakan tertinggi $\mathrm{R} 2=110.88$ gram, $\mathrm{R} 1=108,79$ gram $\mathrm{R} 4=$ 107,39 gram R3 = 105,04 gram dan terendah $\mathrm{R} 0=104,47$ gram. Kisaran rataan konsumsi ransum pada penelitian ini sesuai dengan batasan konsumsi ransum yang dilaporkan Anggorodi (1985) bahwa ayam petelur berumur di atas 5 bulan mengkonsumsi ransum 100-125 gram per ekor per hari. Selanjutnya Patison (1993) mengemukakan bahwa konsumsi ransum ayam petelur yang didapat pada kebutuhan ayam petelur pada fase produksi strain Lohman Brown adalah 110-120 g/ekor/hari.

Tabel 3. Pengaruh Penggunaan Tepung Limbah Labu Kuning Terhadap Konsumsi Ransum (gram/ekor), $\operatorname{HDP}(\%)$ dan Konversi.

\begin{tabular}{lccccc}
\hline \multirow{2}{*}{ Variabel } & \multicolumn{5}{c}{ Perlakuan } \\
\cline { 2 - 6 } & $\mathrm{R}_{0}$ & $\mathrm{R}_{1}$ & $\mathrm{R}_{2}$ & $\mathrm{R}_{3}$ & $\mathrm{R}_{4}$ \\
\hline $\begin{array}{l}\text { Konsumsi } \\
\text { gram/ekor) }\end{array}$ & $104,47 \pm 14,90$ & $108,79 \pm 7,02$ & $110,88 \pm 0,04$ & $105,04 \pm 0,04$ & $107,39 \pm 5,11$ \\
HDP $(\%)$ & $80,81 \pm 14,19$ & $89,42 \pm 2,57$ & $90,45 \pm 10,08$ & $87,06 \pm 8,63$ & $90,99 \pm 5,11$ \\
Konversi & $2,24 \pm 0,24$ & $2,06 \pm 0,02$ & $2,10 \pm 0,20$ & $2,03 \pm 0,11$ & $2,02 \pm 0,09$ \\
\hline
\end{tabular}

Keterangan: Konsumsi, HDP dan Konversi menunjukan tidak berbeda nyata ( $\mathrm{P}>0.05$ ) 
Berdasarkan hasil analisis ragam menunjukan bahwa perlakuan limbah labu kuning memberi pengaruh tidak nyata $(\mathrm{P}>$ 0,05) terhadap konsumsi pakan. Dengan pengertian bahwa pemanfaatan tepung limbah labu kuning sampai $8 \%$ dalam rasum ayam petelur tidak menyebabkan perbedaan konsumsi ransum. Konsumsi ransum yang berbeda tidak nyata antara lain disebabkan oleh kualitas terutama keseimbangan protein dan energi metabolis dalam ransum percobaan yang hampir sama. Pengaruh yang tidak berbeda nyata ini diduga karena ransum ayam petelur yang disusun pada penelitian menggunakan tepung limbah labu kuning dengan imbangan protein 17,58 $18,02 \%$ dan energi metabolis 2745-2835 $\mathrm{Kkal} / \mathrm{kg}$. Kebutuhan protein untuk ayam petelur sebesar 16 - 18\% (Anggorodi, 1985), sedangkan kebutuhan energi metabolis ayam petelur berkisar antara 2650 $-3000 \mathrm{Kkal} / \mathrm{kg}$ ransum. Selanjutnya Tillman et al. (1983). menyatakan, bila kandungan protein dalam ransum cukup dan seimbang maka akan memberikan pengaruh yang sama terhadap konsumsi ransum. Suprijatna et al. (2005). menjelaskan bahwa banyak sedikitnya ransum yang dikonsumsi ternak tergantung juga pada kualitas bahan pakan yang dipergunakan untuk menyusun ransum, keserasian komposisi ransum, nilai nutrisinya sesuai dengan kebutuhan untuk pertumbuhan dan produksi yang optimal serta dipelihara dalam kondisi yang sama. Keadaan ini sesuai dengan pendapat Scott et al. (1992). bahwa imbangan antara protein dan energi dalam ransum mempengaruhi jumlah konsumsi ransum. Leke et al. (2015) mengemukakan bahwa penggunaan tepung tomat sebanyak $8 \%$ dalam pakan ayam petelur MB 402 dengan imbangan protein $17,42 \%$ - 17,49\% dan energi metabolis 2738 - 2766 Kkal memberikan pengaruh tidak nyata terhadap kadar air, protein, lemak dan kolestrol telur.

\section{Pengaruh Perlakuan Terhadap Hen Day Production.}

Berdasarkan data pada Tabel 3 diatas dapat diketahui bahwa rata rata Hen Day Production diperoleh rataan produksi telur tertinggi R4 $(90,99 \%)$ dan terendah produksi telur R0 (80,812\%). Pada penelitian ini rataan produksi telur pada saat puncak produksi adalah 90,99\% . Jika dibandingkan dengan standart produksi telur dikemukakan oleh Scott et al. (1992) dan Wahyu (1992) bahwa puncak produksi telur pada ayam petelur adalah pada kisaran umur 28 - 30 minggu dengan produksi telur 90\% maka tampak puncak produksi pada penelitian ini dicapai. 
Berdasarkan hasil analisis ragam menunjukan bahwa pemberian tepung Limbah Labu Kuning pada ayam ras petelur MB 402 memberikan pengaruh tidak berbeda nyata $(\mathrm{P}>0.05)$ terhadap produksi telur. Tidak nyatanya perbedaan ini karena pemberian tepung limbah labu kuning sampai $8 \%$ dalam ransum belum mempengaruhi kualitas ransum, dalam arti komposisi zat zat makanan dari semua ransum percobaan masih sesuai dengan kebutuhan ayam petelur. Konsumsi ransum yang sama mengakibatkan produksi telur sama. Hal ini sesuai dengan pernyataan Amrullah (2004). menyatakan bahwa faktor utama yang mempegaruhi faktor produksi telur adalah jumlah pakan yang di konsumsi dan kandungan zat makanan dalam pakan. Faktor makanan yang mempengaruhi produksi telur adalah kandungan protein dari makanan tersebut, sebab lebih kurang 50\% berat kering dari telur terdiri protein. Anggorodi (1985).

\section{Australianingrum}

(2005).

mengemukakan bahwa produksi telur sangat dipengaruhi oleh tingkat protein dalam pakan. Hal yang sama juga oleh North dan Bell (1990) bahwa jumlah yang dikonsumsi berpengaruh terhadap produksi ternak, dimana konsumsi pakan yang tinggi akan menghasilkan produksi yang tinggi pula.

\section{Pengaruh Perlakuan Terhadap konversi.}

Konversi ransum menunjukan tingkat efisiensi penggunaan ransum untuk ternak, dan menentukan nilai ekonomis setiap penggunaan ransum yang erat kaitanya dengan biaya produksi (Rasyaf, 1994). Selama penelitian dari masing masing perlakuan diperoleh rataan konversi dari yang terendah R4 (2,02), R3 (2,03), R1 $(2,06)$, R2 $(2,10)$ dan tertinggi R0 $(2,24)$. Konversi pakan ayam petelur selama periode telur pertama maupun kedua berkisar antara 2,0 - 3,0 (Scott et al., 1992).

Berdasarkan hasil analisis ragam menunjukan bahwa perlakuan memberikan pengaruh yang berbeda tidak nyata $(\mathrm{P}>$ 0,05) terhadap konversi ransum. Dengan pengertian bahwa pemanfaatan tepung limbah labu kuning sampai taraf $8 \%$ dalam ransum tidak menyebabkan perbedaan terhadap konversi ransum. Hal ini menunjukan ayam petelur MB 402 yang diberikan ransum mengandung tepung limbah labu kuning sampai taraf $8 \%$ mempunyai kemampuan biologis yang sama dalam merubah makanan yang dikonsumsi menjadi suatu produk. Konversi ransum dapat digunakan sebagai gambaran koefisien produksi, semakin kecil nilai konversi semakin efisien penggunaan ransum. Hal ini sejalan dengan Hurwits et al. (1998). bahwa 
nilai konversi pakan yang semakin kecil menandakan penggunaan pakan yang efisien. Konversi ransum berhubungan dengan konsumsi ransum dan pertambahan produksi ayam.

\section{KESIMPULAN}

Berdasarkan hasil analisa data dan pembahasan terhadap semua variabel pada penelitian ini maka dapat ditarik kesimpulan bahwa penggunaan tepung limbah labu kuning dalam ransum sebanyak $8 \%$ memberikan hasil yang sama terhadap konsumsi ransum, HDP, konversi.

\section{DAFTAR PUSTAKA}

Abun. 2005. Efek ransum mengandung ampas umbi garut produk fermentasi oleh kapang aspergillus niger terhadap imbangan efisensi protein dan konversi ransum pada ayam broiler. Laporan Penelitian. Fakultas Peternakan. Universitas Padjadjaran.

Amrullah. 2004. Nutrisi Ayam Petelur. Penebar Swadaya. Jakarta.

Aggorodi. 1985. Kemajuan Mutakhir Dalam Ilmu Makanan Ternak Unggas. Universitas Indonesia. Jakarta.

Australianingrum, Y. 2005. Pengaruh Daun Singkong ( Mahinot Esculenta) Pada Ransum Ayam Petelur Terhadap Kualitas Telur. Skripsi Jurusan Produksi Ternak Fakultas Pertanian Universitas Sebelas Maret Surakarta.
Fujiwara K., Y. Miyaguchi, A. Toyoda, Y. Nakamura, M. Yamazaki, K. Nakashima and H. Abe. 2008. Effect of fermented soybean "natto" supplement on egg production and qualities, Asian - Aust. J. Anim. Sci. 21 (11): 1610-1615.

Gardjito, Murdijati dan Theresia Fitria Kartika Sari. 2005. Pengaruh Penambahan Asam Sitrat dalam Pembuatan Manisan Kering Labu Kuning (Cucurbita maxima) terhadap Sifat-sifat Produknya. Jurusan Teknologi Pangan dan Hasil Pertanian Fakultas Teknologi Pertanian UGM.

Hurwits, S., D. Sklan, H. Talpas and I. Plavnik. 1998. The effect of dietary protein level on the lysin and arginine requrements of growing chickens. Poultry Science. 77: 698696.

Leke, J R, Jet. S. Mandey, Freddy Nangoy. 2015. Nutrients and cholesterol of eggs affected by dried tomato meal in laying hens diet. International $\mathrm{J}$. on Adv. Sci. Eng. Information Tech. Vol 5(3): 178-180.

National Research Council. 1994. Nutrient Requirement of Poultry. Ninth Revised Edition. National Academy Press, Washington DC.

North and Bell. 1990. Commercial Chicken Production Manual, New York. J. Cent. Eur. Agric.7(1): 135- 140.

Olgun, O., Y. Cufadar and A. O. Yildiz. 2009. Effects of boron supplementation feed with low calcium to diet on performance and egg quality in method laying hens. $\mathbf{J}$ Anim Vet adv. S(4). 650-654 
Duckdrive/com/pdfs/medwell/journa 1s/java/2009/650-654/pdf. Accessed: September $4^{\text {th }}, 2015$.

Pattison, M. 1993. The Healt of Poutry. Lohman Scientific and Tecnikal. Germany.

Rasyaf,M. 1994. Makanan Ayam Broiler. Yayasan Kanisius. Yogyakarta.

Schaible, P.J. 1976.Poultry Feed and Nutrition. Department of Poultry Series, Mighigan state University East Lansing. Michigan.

Scott, M.L., M.C. Nesheir and R.J. Young. 1992. Nutrition of The Chicken. M.L.Scott and Asociation. Itacha New York.

Steel, R.G.D., J.H. Torrie. 1994. Prinsip dan Prosedur Statistika ( Suatu Pendekatan Biometik). Terjemahan : Bambang Sumantri. Jakarta: Gramedia Pustaka Umum.

Suprijatna. 2008. Manifestasi Taraf Protein Ransum Periode Pertumbuhan Terhadap Pertumbuhan Organ Reproduksi dan Dampaknya Pada Per forman Produksi Ayam Petelur
Tipe Medium. Disertasi. Universitas Padjadjaran. Bandung.

Susilorini, E. Sawitri. ME. Muharlien. 2009. Budi Daya 22 Ternak Potensial. Penebar Swadaya. Jakarta.

Tillman, D.A., H. Hartadi, S. Reksohadiprojo, S. Prawirokusumo dan S. Lebdosoekodjo. 1983. Ilmu Makanan Ternak Dasar. Fakultas Peternakan Universitas Gadjah Mada Yogyakarta.

Wahju, J. 1992. Ilmu Nutrisi Unggas. Gadjah Mada University Press. Yogyakarta.

Widayati, E. dan Damayanti, 2000. Aneka Panganan Labu Kuning. Trubus Agrisarana, Surabaya.

Yantimala Dewi. 2011. Pengaruh Pemberian Tepung Kaki Broiler Sebagai Subsitusi tepung Ikan di Dalam Ransum Terhadap Konsumsi Pakan, Bobot Badan dan Konversi Pakan Ayam Arab (gallus turcicus). Skripsi. Jurusan Biologi Fakultas Sains Dan Teknologi. Universitas Islam Negeri Maulana Malik Ibrahim Malang. 